\title{
Development of Seed Vigour Testing Method Using Single Count of Radicle Emergence for True Seed of Shallot (Allium ascalonicum B.)
}

\author{
Blair Moses Kamanga ${ }^{1}$, Endah R. Palupi ${ }^{1, *}$, Eny Widajati ${ }^{2}$, Satriyas Ilyas ${ }^{2}$ \\ ${ }^{1}$ Graduate School (Seed Science and Technology Study Program), Bogor Agricultural University, Jl. Agatis, Dramaga Campus, \\ Bogor, Indonesia. \\ ${ }^{2}$ Department of Agronomy and Horticulture, Faculty of Agriculture, IPB University (Bogor Agricultural University), Dramaga \\ Campus, Bogor 16680, Indonesia.
}

\begin{abstract}
How to cite this paper: Blair Moses Kamanga, Endah R. Palupi, Eny Widajati, Satriyas Ilyas. (2021) Development of Seed Vigour Testing Method Using Single Count of Radicle Emergence for True Seed of Shallot (Allium ascalonicum B.). International Journal of the Science of Food and Agriculture, 5(1), 152-162. DOI: 10.26855/ijfsa.2021.03.019
\end{abstract}

Received: January 30, 2021

Accepted: February 28, 2021

Published: March 11, 2021

*Corresponding author: Endah R. Palupi, Graduate School (Seed Science and Technology Study Program), Bogor Agricultural University, Jl. Agatis, Dramaga Campus, Bogor, Indonesia.

Email: erpalupi@yahoo.co.id

\begin{abstract}
Seed vigour is one of the seed parameters that determines seed quality for successful crop production. An experiment was conducted at Bogor Agricultural University to develop a seed vigour testing method for the true seed of shallot (TSS) using a single count of radicle emergence (RE) that can be used to estimate germination percentage of normal seedlings in the laboratory and field emergence. Nine artificially made seed lots of TSS were used in this experiment which were germinated at two different temperatures i.e., at $20 \pm 1^{\circ} \mathrm{C}$ and at $25 \pm 1^{\circ} \mathrm{C}$ (room temperature). The experiments were arranged in a completely randomized design (CRD) with a repeated measurement, having four replicates. The results showed that a single count of RE at 72 and 68 hours germinated at $20 \pm 1^{\circ} \mathrm{C}$ and $25 \pm 1^{\circ} \mathrm{C}$ respectively, were able to predict germination percentage in the laboratory 12 days after sowing and field emergence 14 days after planting. Regression and correlation analysis values of $\mathrm{RE}$ were predictive to germination percentage with $\mathrm{r}=0.891$ and $\mathrm{R}^{2}=0.951(\mathrm{p}<0.01)$ for seed lots germinated at $20 \pm 1{ }^{\circ} \mathrm{C}$ and $r=0.924$ and $R^{2}=0.875(p=<0.01)$ for seed lots germinated at $25 \pm 1^{\circ} \mathrm{C}$. Furthermore, RE was predictive to field emergence (FE \%) with $\mathrm{r}=0.953$ and $\mathrm{R}^{2}=0.909$ $(p<0.01)$ and $r=0.865$ and $R^{2}=0.732(p<0.01)$ for seed lots germinated at $20 \pm 1^{\circ} \mathrm{C}$ and $25 \pm 1^{\circ} \mathrm{C}$ respectively. A single count of $\mathrm{RE}$ correlated well with other vigour tests at 68 hours and 72 hours for seed lots germinated at $25 \pm 1^{\circ} \mathrm{C}$ and/or $20 \pm 1^{\circ} \mathrm{C}$ respectively, then it can be used as one of the methods for seed vigour test for TSS.
\end{abstract}

\section{Keywords}

Field Emergence, Germination Rate, Mean Germination Time, Radicle, Viability

\section{Introduction}

Shallot (Allium ascalonicum B.) is a popular bulb vegetable cum-spice that is related to common onion, as part of the same botanical family (Liliaceae) that form more bulbs in a cluster. It is one of the horticultural crops that has high economic value due to high demand at the market [1]. Shallot (red onion) cultivation has been using bulbs originating from past crops as planting material (vegetative propagation). After a long and continuous usage of bulbs as seed, there has been a decrease in shallot production both quantitatively and qualitatively due to loss in vigour and viral diseases. The main challenge in increasing the production of shallots, among other factors is that there is no guaranteed availability of TSS with high quality that can produce high-yield up to 19 tons ha ${ }^{-1}$ of good quality [2]. 
Seed vigour is one of the most important quality characteristics that must be thoroughly assessed in order supplement germination in order to obtain quality information about the performance of seed lots in the laboratory and in the field. Looking into the complexity as regard to seed vigour, the ISTA congress in 1995 adopted the definition of seed vigour as "the sum total of those properties of the seed which determine the level of activity and performance of the seed or seed lot during germination and seedling emergence". Seed deterioration resulting from production and storage factors are the major cause of the differences in seed vigour that result in low seedling emergence in both laboratory and field hence a loss in seed vigour [3, 4]. TSS is known to be sensitive to storage conditions and can lose vigour quickly after harvesting due to seed deterioration. Generally, deterioration may reduce seedling emergence in both laboratory and in the field, therefore a quick vigour testing method would be valuable for ranking seed lots and estimates its field emergence. A simpler method to assess germination rate is to use a single count of radicle emergence in the early stages of seed germination.

Radicle emergence has been used as a method for vigour test in various seed crops and there is evidence that an early single count of radicle emergence during germination was related to field emergence in grass native species [5] and in oilseed rape [6]. The use of RE method in determining seed vigour in other crops was based on continuous observations made during the development of radicle from the seed. Studies have shown that commercial seed lots that have low count of RE during early germination, tend to have a lower count of normal seedlings i.e., in maize [7], pepper [8], radish [9] and oilseed rape [6].

Single counts of RE correlated well with germination percentage in some seed lots of oilseed rape following prolonged uncontrolled storage [10]. Furthermore, [11] concluded that RE was useful to estimate normal germination in ten commercial seed lots of radish after being stored for some months. Nevertheless, there is inadequate evidence that an early count of RE can predict field emergence and normal seedlings for TSS lots having high and low vigour. Methods involving single count of RE had been verified in maize seed [12] and has been proposed to evaluate vigour in vegetable seeds [13]. According to [6], the development of RE as a method for vigour test in seeds of other crop came in place after several trials in laboratory and in the field, as such the new method for vigour test was determined by an early single count of radicle emergence $(2 \mathrm{~mm})$ at different period of time (hours). The time selection of a single count for example in maize was based on mean germination time to find the maximum time (hours) at which a single count of RE could be used [14].

High early count of RE during germination is an indication of high seed vigour and low count basically indicates low seed vigour. Generally, there is no information on a single count of RE as a seed vigour testing method for TSS, hence more studies were needed to develop a method that could accurately predict field emergence. Currently, no method for vigour test has been validated by ISTA for TSS. However, electrical conductivity [15] and accelerated ageing [16] have been used in onion true seed to determine the vigour of Liliaceae seed family. However, the methods are expensive, time-consuming and require expertise to perform. The basis for a single count of RE as a seed vigour testing method is that; it is a simple, cheap and quick way of determining seed vigour of a seed lot. This research was therefore aimed at developing a seed vigour testing method that can be used to predict field seedling emergence using a single count of radicle emergence for true seeds of shallot.

\section{Materials and Methods}

\subsection{Seed materials}

The research was conducted in a seed testing laboratory and Leuwikopo experimental farm, Department of Agronomy and Horticulture, Bogor Agricultural University, Dramaga Indonesia from February to July 2019. Nine seed lots of TSS were used in this experiment from two varieties namely Bima and Trisula produced at an experimental station of Indonesian Vegetables Research Institute (IVEGRI) in North Sumatra. The seed was harvested on 3rd and 12th October 2018 respectively. The following seed lots namely BM1, BM2, BM3, BM4, BM5 and TS1, TS2, TS3, TS4 for Bima and Trisula varieties respectively.

The seed lots were artificially made by accelerated ageing treatment using plastic boxes $(11.0 \times 11.0$ x $3.5 \mathrm{~cm})$ having a suspended aluminium/mesh screen inside on which the seeds were placed. Approximately 5.0g of seed was weighed and uniformly distributed on a mesh and distilled water $(40 \mathrm{ml})$ was added to the bottom of each plastic box. The boxes were covered and placed in an incubator at $39-41^{\circ} \mathrm{C}$ with relative humidity of $90-100 \%$ for $0,24,36,48$ and 72 hours according to [17] and the process was repeated to make sure that different seed lots were obtained. After the treatment, the seeds were air-dried and stored for 14 days and later subjected to germination test using top of paper method at $20 \pm 1^{\circ} \mathrm{C}$ and $25 \pm 1^{\circ} \mathrm{C}$. Evaluation of normal seedlings were performed 6 days after sowing (first count) and 12 days after sowing (final count) and the results were expressed as a mean percentage of normal seedlings for each seed lot. Seed lots were categorized as high vigour (GP>80\%), medium vigour $(70<\mathrm{GP}<80 \%)$, low vigour $(60<\mathrm{GP}<70 \%)$ and deteriorated seed $(\mathrm{GP}<50 \%)$. 


\subsection{Radicle emergence, vigour test in the laboratory and in the field}

The experiment was conducted to determine the time range for a single count of RE. Observations were made every four hours starting from 48 hours to 80 hours (Based on pre-experiment) after sowing. RE test was conducted using top of paper (TP) method planted in plastic containers $(28.5 \times 19.5 \times 13.5 \mathrm{~cm})$ on four towel tissue paper moistened with distilled water. The seeds were incubated in a standard germinator at $20 \pm 1^{\circ} \mathrm{C}$ and $25 \pm 1{ }^{\circ} \mathrm{C}$ and seeds with a radicle protrusion at least $2 \mathrm{~mm}$ were considered to have been germinated and were counted according to [12].

Seed vigour tests in the laboratory were based on the following variables: mean germination time (MGT), vigour index (VI), speed of germination and electrical conductivity test $\left(E C-\mu \mathrm{Sm}^{-1} \mathrm{~g}^{-1}\right)$. Besides vigour tests, germination tests were also conducted where the first count of normal seedlings was conducted 6 days after planting and the final count of normal seedlings (12 days after planting). Each treatment used 100 seeds which were replicated four times. Field emergence (FE), field emergence rate (FER) and mean emergence time (MET) were done to determine seedling vigour in the field. 100 seeds were sown directly on the seedbeds in natural field conditions. A drill was constructed on seed beds where seeds were sown, watering was done on daily basis to maintain moisture levels in the soil. Virgin loamy soil mixed with sand and compost manure were used as planting media in the field.

\subsection{Experimental design and observations}

The experiment was arranged in a completely randomized design (CRD) for laboratory vigour tests with one factor i.e., seed lots with 9 levels. For RE, experiments were arranged in CRD with repeated measurements/observations, RE observations were taken every 4 hours for at least 9 times at different time of emergence starting from 48 hours after sowing up to 80 hours. Each treatment was replicated 4 times; hence 36 experimental units were laid off. Seedling vigour test in the field i.e., FER and MET, and FE were arranged in a randomized complete block design (RCBD). Radicle emergence percentages were calculated by dividing the number of newly emerged seed at a given time by the total number of seeds sown multiplied by 100.Laboratory germination (\%) was calculated by summing up normal germinated seedling on final count (12 days) after sowing, then dividing by the total number of seeds planted multiplied by 100.

Mean germination time (MGT) was calculated by the formula given by [18];

$$
\operatorname{MGT}=\frac{\Sigma(\mathrm{n} . \mathrm{D})}{\Sigma(\mathrm{n})}
$$

Where;

$\mathrm{n}=$ Number of seedlings emerged at time $\mathrm{D}$.

$\mathrm{D}=$ Days from the beginning of the emergence.

$\Sigma \mathrm{n}=$ Final number of seeds germinated.

Vigour index (VI) tests were determined according to [12], i.e., the number of seedlings germinated normally on the first count (6 days after planting) expressed as a percentage. Speed of germination (germination rate) was calculated according to [19] and [20].

Germination rate $=\frac{X 1}{Y 1}+\frac{X 2}{Y 2}+\cdots+\frac{X n}{Y n}$

Where :

$\mathrm{X}_{1}, \mathrm{X}_{2}$ and $\mathrm{X}_{\mathrm{n}}=$ numbers of seeds germinated on the $1^{\text {st }}, 2^{\text {nd }}$, and $\mathrm{n}^{\text {th }}$ hour,

$\mathrm{Y}_{1}, \mathrm{Y}_{2}$, and $\mathrm{Y}_{\mathrm{n}}=$ number of hours from sowing to $1^{\text {st }}, 2^{\text {nd }}$, and $\mathrm{n}^{\text {th }}$ count, respectively.

Electrical conductivity (EC) was conducted using approximately $0.5 \mathrm{~g}$ of seeds with 4 replicates per seed lot and placed in $100 \mathrm{ml}$ glass jars [21].The seed moisture content was raised from $7.1 \%$ to between $10 \%-30 \%$ by placing the seed on top of the moist tissue paper for 3 hours before being placed in glass jars. Then, $50 \mathrm{ml}$ double distilled water of $\mathrm{EC}<5 \mu \mathrm{Sm}^{-1} \mathrm{~g}^{-1}$ was added in each jar. The jars were tightly closed with aluminum foil. Following this, the jars were placed in an incubator at $20 \pm 2^{\circ} \mathrm{C}$ for $24-28$ hours ( \pm 15 minutes). The electrical conductivity was determined by a conductivity meter and the readings were expressed in $\mu \mathrm{S} \mathrm{cm}^{-1} \mathrm{~g}^{-1}$ of seeds. EC values were calculated using the formula below.

$$
\text { EC }\left(\mu \mathrm{S} \mathrm{cm}^{-1} \mathrm{~g}^{-1}\right)=\frac{\text { Conductivity }\left(\mu \mathrm{S} \mathrm{cm}^{-1}\right)-\text { background reading }}{\text { Weight of replicates }(\mathrm{g})}
$$

Field emergence (\%) was calculated as the percentage of seeds that develop into normal seedlings 14 days after planting. The normal seedlings were those that had germinated with hypocotyl reached at least $2 \mathrm{~cm}$ long from the soil surface with a J shape. Mean emergence time (MET) was determined by counting the number of emerged seedlings with at least $2 \mathrm{~cm}$ hypocotyl length every day from the day of planting until the $14^{\text {th }}$ day [17] using the following formula: 


$$
\operatorname{MET}(\text { days })=\frac{\Sigma(\mathrm{n} \times \mathrm{t})}{\text { Total seeds germinated }}
$$

Where:

$\mathrm{n}$ : total number of newly germinated seeds at time $-\mathrm{t}$

$\mathrm{t}$ : days after sowing (DAS)

\subsection{Data analysis}

Analysis of variance was performed to determine the level of significance, and DMRT test at 5\% level of significance was used to compare the mean value between the treatments on the observed indicator of RE. Simple linear regression analysis was performed to obtain the correlation coefficients on treatment means in order to determine the relationship between the radicle emergence, germination percentage, field emergence and other vigour tests. R-Studio[22] package, Minitab and Microsoft excel programs were used in data analysis.

\section{Results and Discussion}

\subsection{Vigour tests of nine seed lots of TSS in the laboratory and in the field}

There were significant differences in seed vigour and viability parameters among the seed lots germinated in a standard germinator at $20 \pm 1^{\circ} \mathrm{C}$ and at $25 \pm 1{ }^{\circ} \mathrm{C}$ ( Table 1). TS1 had the highest vigour index (VI) which was more than $80 \%$ as compared to other treatments at both germinating temperatures. BM5 and TS4 had the lowest vigour index (30.0\%) and (24.5\%) at $20 \pm 1^{\circ} \mathrm{C}$ as compared to $39.5 \%$ and $44.0 \%$ at $25 \pm 1^{\circ} \mathrm{C}$. Germination percentage (GP) ranged from $53 \%$ to $94 \%$ with BM1 and TS1 having the highest germination (>90\%) and TS4 with the lowest germination $(<60 \%)$ at both germinating temperatures.

Mean germination time (MGT) varied significantly among seed lots, however germination at $25 \pm 1^{\circ} \mathrm{C}$ resulted in more variation than at $20 \pm 1^{\circ} \mathrm{C}$. BM1 and TS1 had significantly lower number of days to complete germination with mean germination time (MGT) 2.08 days and 2.22 days at $25 \pm 1^{\circ} \mathrm{C}$ which was an indication of rapid germination as compared to 2.28 and 2.23 days at $20 \pm 1^{\circ} \mathrm{C}$ respectively (Table 1). Meanwhile BM5 and TS4 recorded the highest MGT for seed lots germinated at both temperatures. The rest of the seed lots had statistically similar MGT.

Germination rate (GR) revealed a clear difference in seed vigour with BM1 germinated at $25 \pm 1^{\circ} \mathrm{C}$ having higher number of seeds germinated per day (19.39) followed by TS1 (18.2) germinated at the same temperature (Table 1). Furthermore, seed lots germinated at $20 \pm 1^{\circ} \mathrm{C}$ had relatively lower number seeds germinated per day with BM1 having 17.88 and TS1 having 16.0 seeds which can be attributed to lower temperatures. TS4 had the least GR of 9.11 and 10.7 seeds germinated per day at $20 \pm 1^{\circ} \mathrm{C}$ and $25 \pm 1^{\circ} \mathrm{C}$ respectively. The rest of the treatments had similar germination rate ranged from 12 to 15 seeds. The differences in seed vigour in this research were due to adverse environmental conditions caused by accelerated ageing which fasten the deterioration process of seeds. Seed deterioration decreases seed vigour and the ability of the seed to survive. Research has shown that deteriorated seeds take more time to germinate and are likely to produce weak seedlings [23].

Table 1. Seed vigour and viability tests in laboratory germinated at a standard temperature of $20 \pm 1{ }^{\circ} \mathrm{C}$ and at $25 \pm 1{ }^{\circ} \mathrm{C}$

\begin{tabular}{|c|c|c|c|c|c|c|c|c|}
\hline \multirow[b]{2}{*}{ Seed lot } & \multicolumn{4}{|c|}{ Seed lots germinated at $20 \pm 1^{\circ} \mathrm{C}$} & \multicolumn{4}{|c|}{ Seed lots germinated at $25 \pm 1^{\circ} \mathrm{C}$} \\
\hline & VI(\%) & GP (\%) & MGT(days) & GR (S/d) & VI(\%) & GP (\%) & MGT(days) & GR (S/d) \\
\hline BM1 & $73.0 \mathrm{~b}$ & $90.5 a$ & $2.28 \mathrm{~b}$ & $17.88 \mathrm{a}$ & $75.0 \mathrm{ab}$ & $94.5 \mathrm{a}$ & $2.08 \mathrm{e}$ & $19.39 a$ \\
\hline BM2 & 55.5bcd & $82.5 \mathrm{ab}$ & $2.34 b$ & $15.3 \mathrm{bc}$ & $63.0 \mathrm{bc}$ & $82.5 \mathrm{ab}$ & 2.28de & $15.73 b$ \\
\hline BM3 & $58.5 b c$ & $78.0 \mathrm{bc}$ & $2.41 \mathrm{~b}$ & $13.4 \mathrm{~cd}$ & $64.5 \mathrm{bc}$ & $78.0 \mathrm{bc}$ & $2.27 \mathrm{de}$ & $14.40 \mathrm{~b}$ \\
\hline BM4 & 50.5de & 72.5bcd & $2.18 \mathrm{~b}$ & 15.5 cde & $57.5 \mathrm{~cd}$ & 72.5bcd & 2.67cde & $15.45 \mathrm{ab}$ \\
\hline BM5 & $30.0 \mathrm{e}$ & 66.0de & $3.86 b$ & 8.58cde & $39.5 f$ & 60.0de & $3.86 b$ & 12.69ab \\
\hline TS1 & $80.5 \mathrm{a}$ & $86.5 a$ & $2.23 \mathrm{~b}$ & 16.0ab & $90.5 a$ & $90.5 a$ & 2.22de & 18.16ab \\
\hline TS2 & 44.0bcd & $77.5 b c$ & $2.64 \mathrm{ab}$ & 14.9bcd & $58.5 \mathrm{~cd}$ & $77.5 b c$ & $2.87 \mathrm{~cd}$ & $15.35 b$ \\
\hline TS3 & 41.0cde & $70.5 \mathrm{~cd}$ & $2.33 b$ & 14.2de & 51.0de & $70.5 \mathrm{~cd}$ & $2.97 \mathrm{c}$ & $12.13 b$ \\
\hline TS4 & $24.5 f$ & $59.0 \mathrm{e}$ & $3.11 \mathrm{a}$ & $9.11 \mathrm{e}$ & $44.0 \mathrm{ef}$ & 53.5e & $4.56 \mathrm{a}$ & $10.69 b$ \\
\hline P-value & * & $*$ & * & $*$ & $*$ & * & $*$ & $*$ \\
\hline CV (\%) & 11.9 & 8.45 & 14.91 & 10.2 & 10.12 & 9.15 & 14.8 & 14.2 \\
\hline
\end{tabular}

VI = Vigour index, GP = germination percentage (after 12 days), MGT = mean germination time (days), GR = germination rate (seeds/day), and $\mathrm{CV}=$ coefficient of variation. Means with similar preceding letters within the same column are not significant difference at 0.05 level of significance, * = highly significant at $5 \%$. 
Comparisons of germination percentages and mean germination time at both germinating temperatures revealed the clear differences in the level of seed viability and vigour among the lots. Seed lots that have low MGT tend to germinate quickly as compared to seed lots with higher MGT. These results confirmed that the seed lots used in this research were of different seed vigour. Developing a seed testing method depends on the number of available seed lots which are determined based on vigour index (\%), germination percentage (\%), germination rate (GR) and mean germination time (MGT) and other seed vigour parameters. These parameters indicate the level of seed quality among the seed lots and cause variations during seed germination. Generally, seed deterioration causes physical, biochemical, cytological and physiological changes in seeds due to damaged cells and hence, a delay in seed germination [24].

Field emergence (FE) of nine seed lots of TSS produced a different range of normal seedlings varying between $47 \%$ and $90 \%$ which were all statistically different (Table 2). TS1 had significantly higher field emergence (90.3\%) followed by BM1 (87.5\%). Furthermore, BM5 and TS4 had the lowest field emergence i.e., 51\% and $47.5 \%$ respectively. Field emergence rates (FER) were statistically different among seed lots with BM1 having higher emergence rate (14.8\%) as compared BM5 (9\%). TS3 and TS4 had the lowest number of seeds emerged (7.99\%) per day. Furthermore, seed lots also differ in mean emergence time (MET) with BM5 and TS4 having significantly higher MET (11.49 days) and (10.22 days), respectively. However, the rest of the seed lots had similar MET ranging from 6.22 to 7.18. Slow rate of germination among seed lots are caused by deterioration of seeds which reduces the capacity of the seed to germinate and has been highly linked to seed ageing in many crop species [25].

Electrical conductivity (EC) which measures the dissolved solutes of seeds when soaked in distilled water due to loss of integrity of cellular system was also significant. Results indicated that BM1 had significantly lower value of EC $\left(85.69 \mu \mathrm{S} . \mathrm{cm}^{-1} \mathrm{~g}^{-1}\right)$ followed by TS1 $\left(101 \mu \mathrm{S} . \mathrm{cm}^{-1} \mathrm{~g}^{-1}\right)$. TS4 had $156.93 \mu \mathrm{S} . \mathrm{cm}^{-1} \mathrm{~g}^{-1}$ which was higher than the rest of the lots and can be due to damaged cell membrane caused by the process of accelerated ageing. However, the rest of the seed lots had statistically similar values of EC with the coefficient of variation of $13.4 \%$. Seed lots which were artificially made showed variation in vigour parameters because ageing decreases the proportion of normal seedlings and increases solute leakage (EC) which was also observed in other seed crops such radish [11] and cabbage [26].

There are many factors that cause seed deterioration ranging from production and storage factors with storage factors being the major cause of differences in seed vigour that results in low seedling emergence in the laboratory and in the field $[3,4]$. Low seed vigour differences in this research was caused by the process of accelerated ageing of seeds at different period of time, hence a difference in MGT, germination percentage and germination rate. A slow rate of germination has been described as a basic indicator of higher deterioration in seeds. The results obtained in this research on low MGT however conquer with [8, 13] and [27] in which various seed crops whose MGT was found to be related to seedling emergence in controlled environments and in field conditions, and seeds with low MGT were found to be seed with high vigour.

Table 2. Seed vigour and viability tests in the field for 9 TSS seed lots

\begin{tabular}{ccccc}
\hline Seed Lot & FE (\%) & FER (\% Seedling/day) & MET (Days) & EC $\left(\mu \mathrm{S} . \mathrm{cm}^{-1} \mathrm{~g}^{-1}\right)$ \\
\hline BM1 & $87.5 \mathrm{ab}$ & $14.8 \mathrm{a}$ & $6.02 \mathrm{~b}$ & $85.69 \mathrm{f}$ \\
BM2 & $78.3 \mathrm{ab}$ & $13.2 \mathrm{ab}$ & $6.83 \mathrm{~b}$ & $112.62 \mathrm{de}$ \\
BM3 & $77.5 \mathrm{ab}$ & $12.6 \mathrm{abc}$ & $6.77 \mathrm{~b}$ & $120.77 \mathrm{~cd}$ \\
BM4 & $73.3 \mathrm{~b}$ & $10.9 \mathrm{bcd}$ & $7.18 \mathrm{~b}$ & $125.20 \mathrm{~cd}$ \\
BM5 & $51.0 \mathrm{c}$ & $9.0 \mathrm{~d}$ & $11.49 \mathrm{a}$ & $146.95 \mathrm{abc}$ \\
TS1 & $90.3 \mathrm{a}$ & $13.0 \mathrm{ab}$ & $6.22 \mathrm{~b}$ & $101.60 \mathrm{~d}$ \\
TS2 & $84.5 \mathrm{ab}$ & $13.1 \mathrm{ab}$ & $6.99 \mathrm{~b}$ & $92.36 \mathrm{ef}$ \\
TS3 & $59.3 \mathrm{c}$ & $7.9 \mathrm{~d}$ & $7.87 \mathrm{~b}$ & $153.09 \mathrm{ab}$ \\
TS4 & $47.5 \mathrm{~d}$ & $7.9 \mathrm{~cd}$ & $10.22 \mathrm{a}$ & $156.93 \mathrm{a}$ \\
P-value & $* *$ & $* *$ & $* *$ & $* *$ \\
CV (\%) & 12.5 & 16.2 & 25.3 & 13.4 \\
\hline
\end{tabular}

$\mathrm{FE}=$ field emergence, $\mathrm{FER}$ = field emergence rate, MET = mean emergence time, EC = electrical conductivity. Means with preceding letters within the same column are not significant difference at 0.05 level of significance, ${ }^{*}=$ highly significant at $5 \%$.

\subsection{Determination of seed vigour using radicle emergence}

The results showed significant differences among seed lots and time of emergence from 48 to 80 hours (Figure 1). 
Seed lots germinated at $20 \pm 1^{\circ} \mathrm{C}$ continued to germinate up to 80 hours (Figure $1 \mathrm{~A}$ ). No further significant differences from 68 hours to 80 hours for seed lots germinated at $25 \pm 1^{\circ} \mathrm{C}$ during emergence were observed (Figure 1B). More uniform radicle emergence was observed for seed lots germinated at $20 \pm 1^{\circ} \mathrm{C}$ as compared to those germinated at $25 \pm 1^{\circ} \mathrm{C}$. Seed lots BM1 and TS1 had significantly high emergence per observation than the rest of the lots. The two slowest lots with least RE were TS4 and BM5 at both germinating temperatures and were considered as seed lots with low vigour. These were followed by an intermediate group TS2, TS3, BM2 and BM3 and finally a group of seeds lots that emerged most rapidly TS1 and BM1 which achieved the highest final count of RE.

The results on RE provide evidence that seeds that have started deteriorating requires more time to start germinating than good quality seed with high vigour. Previous research has shown that seeds that have started to deteriorate have longer lag period than unaged ones, and they are reflected by the time needed for radicle emergence [4]. Single count of RE identified seed lots that had a higher germination i.e., those above $80 \%$ and low vigour seed lots having higher MGT and lower GR. In addition to that, the use of RE counts would be a quick and inexpensive method of seed quality analysis in as far as the current seed industry is concerned together with other seed vigour testing methods. The method would provide an opportunity for seed testing laboratories to easily test for seed vigour using early count of RE which can predict the final percentage of seedlings in the laboratory and in the field. Generally, slower RE indicated higher MGT and faster RE indicated lower MGT which can directly be linked to seed ageing and support the ageing-repair hypothesis that has been proposed as the basis of all vigour tests [4] More uniform radicle emergence was observed in seed lots germinated at $20 \pm 1^{\circ} \mathrm{C}$ as compared to seed lots germinated at $25 \pm 1^{\circ} \mathrm{C}$.

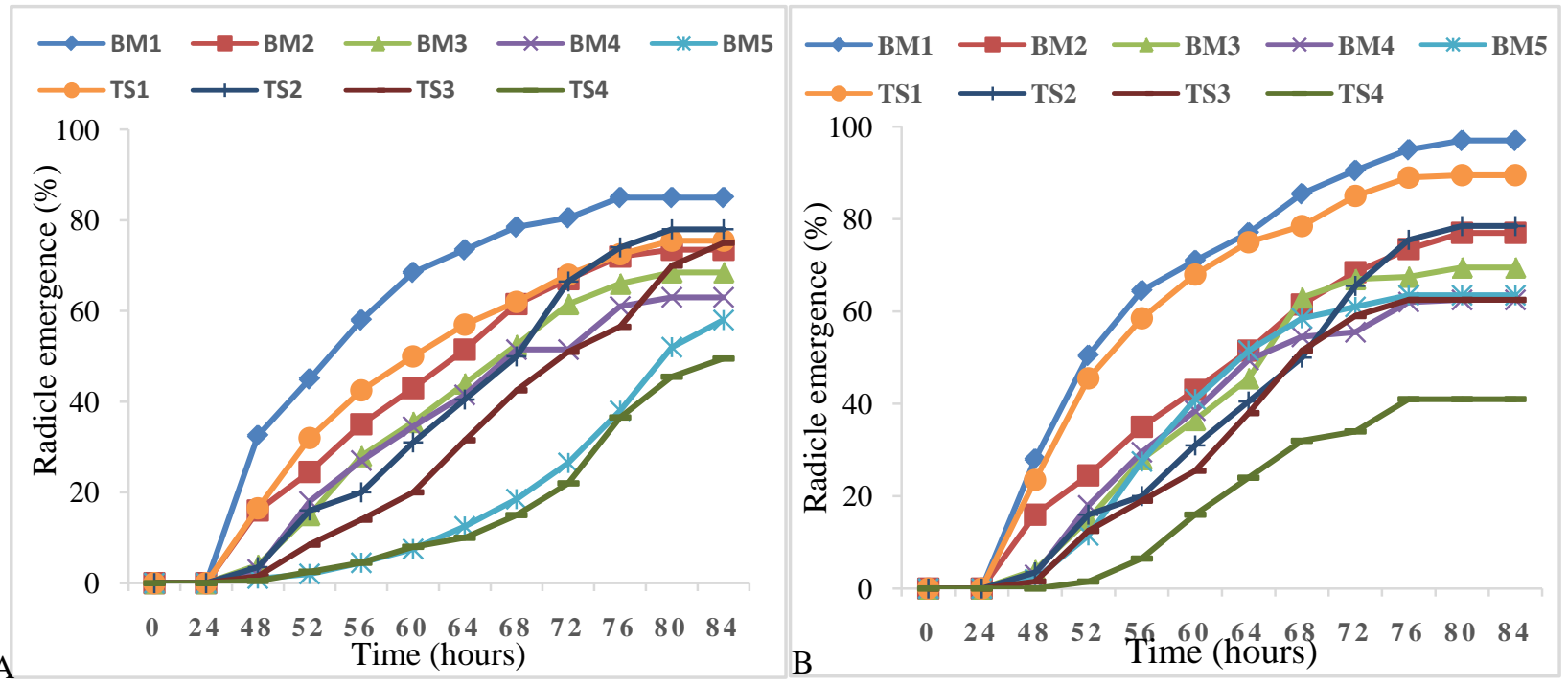

Figure 1. Radicle emergence of seed lots germinated at $20 \pm 1^{\circ} \mathrm{C}(\mathrm{A})$ and at $25 \pm 1^{\circ} \mathrm{C}(\mathrm{B})$ observed at a different time in a standard germinator.

\subsection{Correlation analysis}

Correlation coefficients for seed lots germinated at $20 \pm 1^{\circ} \mathrm{C}$ and at $25 \pm 1^{\circ} \mathrm{C}$ showed strong and high correlation between RE and seed vigour parameters which were significant $(p<0.01)$. Furthermore, seed lots germinated at $20 \pm \mathrm{PC}$ had higher correlation values as compared to those germinated at $25 \pm 1^{\circ} \mathrm{C}$ except for MGT for seed lots germinated at $20 \pm 2^{\circ} \mathrm{C}$. The correlation values between a single count of radicle emergence provide vital information about the relationship between RE and other seed vigour and seedling vigour parameters. High correlation values for seed lots germinated at $20 \pm 1^{\circ} \mathrm{C}$ could be attributed to slower and uniform protrusion of the radicle from the seed among the seed lots.

Correlation analysis between RE and vigour parameters starting from 60 hours to 80 hours revealed that seed vigour parameters in the laboratory and seedling vigour in the field correlated well with RE at both germinating temperatures. Basing on correlation analysis, 68 hours at $25 \pm 1^{\circ} \mathrm{C}$ and 72 hours at $20 \pm \mathrm{PC}$ were selected as appropriate time for RE observation because of high correlation coefficient for GP, MGT and FE. Correlation coefficients were higher for seed lots germinated at $20 \pm 1^{\circ} \mathrm{C}$ as compared to those at $25 \pm 1^{\circ} \mathrm{C}$ which makes $20 \pm 1^{\circ} \mathrm{Cmore}$ suitable temperature for a single count of RE as a vigour testing method. Correlation values differ among seed lots due to differences in seed vigour which was caused by adverse condition during the process of accelerating ageing. Normally, accelerating ageing treatments reduces the capacity of the seed to germinate due to the damaged cell membrane, embryo, other food reserves and their respective enzymes that play an important role during imbibition and seed germination. 
Table 3. Correlation analysis between radicle emergency and vigour parameters in the laboratory and in the field

\begin{tabular}{|c|c|c|c|c|c|c|}
\hline \multirow{2}{*}{ Parameter } & \multicolumn{6}{|c|}{ Time (hours from sowing) when RE start counted at $20 \pm 1^{\circ} \mathrm{C}$} \\
\hline & 60 & 64 & 68 & 72 & 76 & 80 \\
\hline VI & $0.917 * *$ & $0.926 * *$ & $0.886^{* *}$ & $0.821^{* *}$ & $0.793^{* *}$ & $0.792 * *$ \\
\hline GP & $0.904 * *$ & $0.918 * *$ & $0.886 * *$ & $0.891 * *$ & $0.872 * *$ & $0.908 * *$ \\
\hline MGT & $-0.592^{\mathrm{ns}}$ & $-0.653^{\mathrm{ns}}$ & $-0.683^{* *}$ & $-0.543^{\text {ns }}$ & $-0.557^{\mathrm{ns}}$ & $-0.597^{\mathrm{ns}}$ \\
\hline GR & $0.897 * *$ & $0.939 * *$ & $0.962 * *$ & $0.934 * *$ & $0.922 * *$ & $0.917 * *$ \\
\hline EC & $-0.862 * *$ & $-0.864 * *$ & $-0.844^{* *}$ & $-0.927 * *$ & $-0.898 * *$ & $-0.854 * *$ \\
\hline MET & $-0.861 * *$ & $-0.912 * *$ & $-0.934 * *$ & $-0.930 * *$ & $-0.924 * *$ & $-0.881 * *$ \\
\hline FER & $0.892 * *$ & $0.890 * *$ & $0.872 * *$ & $0.911^{* *}$ & $0.890 * *$ & $0.820 * *$ \\
\hline \multirow[t]{2}{*}{ FE } & $0.885^{* *}$ & $0.916^{* *}$ & $0.908^{* *}$ & $0.953 * *$ & $0.932 * *$ & $0.890^{*}$ \\
\hline & \multicolumn{6}{|c|}{ Time (hours from sowing) when $\mathrm{RE}$ start counted at $25 \pm 1^{\circ} \mathrm{C}$} \\
\hline VI & $0.800^{* *}$ & $0.787 * *$ & $0.807 * *$ & $0.773 * *$ & $0.798^{* *}$ & $0.810^{* *}$ \\
\hline GP & $0.823^{* *}$ & $0.803^{* *}$ & $0.924 * *$ & $0.908 * *$ & $0.840^{* *}$ & $0.927 * *$ \\
\hline MGT & $-0.682 * *$ & $-0.701 * *$ & $-0.818^{* *}$ & $-0.823^{* *}$ & $-0.802 * *$ & $-0.828 * *$ \\
\hline GR & $0.911 * *$ & $0.896 * *$ & $-0.936 * *$ & $0.905^{* *}$ & $-0.871 * *$ & $-0.935^{* *}$ \\
\hline EC & $-0.714 * *$ & $-0.685^{* *}$ & $-0.879 * *$ & $-0.876 * *$ & $-0.686 * *$ & $-0.894 * *$ \\
\hline MET & $-0.785^{* *}$ & $-0.786 * *$ & $-0.904 * *$ & $-0.899 * *$ & $-0.846^{* *}$ & $-0.915^{* *}$ \\
\hline FER & $0.729 * *$ & $0.696 * *$ & $0.860 * *$ & $0.868 * *$ & $0.733^{* *}$ & $0.875^{* *}$ \\
\hline $\mathrm{FE}$ & $0.710^{* *}$ & $0.702 * *$ & $0.865^{* *}$ & $0.857 * *$ & $0.835^{* *}$ & $0.880 * *$ \\
\hline
\end{tabular}

Level of significance $* *=P<0.01, V I=$ Vigour index, GP = germination percentage of normal seedlings after 12 days, MGT = mean germination time (days), $\mathrm{GR}=$ Germination rate (seeds germinated per day), $\mathrm{EC}=$ electrical conductivity $\left(\mu \mathrm{S} . \mathrm{cm}^{-1} \mathrm{~g}^{-1}\right), \mathrm{MET}=$ Mean emergence time, FER $=$ Field emergence rate, FE $=$ Field emergence.

\subsection{Relationship between $R E$ and seed vigour tests in the laboratory}

Radicle emergence at both temperatures (Figure 1a) was able to predict germination (\%) with coefficient of determination $R^{2}=0.951$ for seed lots germinated at $20 \pm 1^{\circ} \mathrm{C}$ and $R^{2}=0.875$ for seed lots germinated at and $25 \pm 1{ }^{\circ} \mathrm{C}$. Single counts of $\mathrm{RE}$ at $20 \pm 1^{\circ} \mathrm{C}$ were more accurate and predic tive to germination percentage in the laboratory with $\mathrm{R}^{2}$ greater than $R^{2}$ at $25 \pm 1^{\circ} \mathrm{C}$. A single count of RE was able predict to MGT with $R^{2}=0.801\left(20 \pm 1^{\circ} \mathrm{C}\right)$ and $R^{2}=0.453\left(25 \pm 1^{\circ} \mathrm{C}\right)$ which makes $20 \pm 1^{\circ} \mathrm{Can}$ appropriate temperature for RE. The current results have revealed that a single count of RE can be used to as a method for seed vigour test as it precisely predicted germination for true seed of shallot. These results in TSS are similar to results in other species i.e., Avena sativa and Elymus nutans [28] where the rate of germination assessed by single count of RE and MGT were predictive to normal seedlings in the laboratory and in the field.

$\mathrm{RE}$ further were predictive to germination rate (Figure 2c) with a coefficient of determination $\mathrm{R}^{2}=0.831$ at $25 \pm 1^{\circ} \mathrm{C}$ and $R^{2}=0.872$ at $20 \pm 1^{\circ} \mathrm{C}$ which were all significant $(\mathrm{P}=<0.01)$. $\mathrm{RE}$ was also related to vigour index which measures the power of seed germination or first count ( 6 days after sowing) with $\mathrm{R}^{2}=0.676$ for seed lots germinated at $20 \pm 1^{\circ} \mathrm{C}$ and $\mathrm{R}^{2}=0.597$ for seed lots germinated at $25 \pm 1^{\circ} \mathrm{C}$ (Figure 2d). The result provides a set of information that a single count of RE can provide details about seed vigour to farmers and seed producers. High correlation values and coefficient of determination in this research provide enough evidence that a single count of RE can be an alternative way to predict seed vigour of TSS. These results agree with [10] who found that a single count of RE correlated well with germination percentage of oilseed rape following uncontrolled storage. Furthermore, the use of RE was found to be predictive to germination percentage and MGT in ten commercial seed lots of radish $\mathrm{R}^{2}>0.95$ [11].

Finally, there were high coefficients of determination for electrical conductivity with seed lots germinated at $20 \pm 1^{\circ} \mathrm{C}$ having higher $\mathrm{R}^{2}=0.798$ than $\mathrm{R}^{2}=0.601$ at $25 \pm 1^{\circ} \mathrm{C}$ (Figure 2e). This indicated that $\mathrm{RE}$ can predict seed vigour parameters in the laboratory based on EC. High coefficient of determination $\left(\mathrm{R}^{2}\right)$ for EC indicates that RE has the potential to predict EC (leakage) of TSS. Similar results were reported by [29] where artificially aged seeds of Brassica spp., with higher levels of leakage (EC) was reported from non-germinated seeds and seeds that produced abnormal seedlings. However, in this research higher EC values were observed in low vigour seeds i.e., BM5 and TS4 (Table 1). Furthermore, our findings concur with [11] who reported that percentage of normal seedlings of commercially seed lots of radish were predictive and related to EC. This research has provided the basis for vigour test using a single count of RE 
based on higher $\mathrm{R}^{2}$ with other vigour parameters. The use of a single count of $\mathrm{RE}$ as a method for vigour test has been found to be effective, quick and cheap following successful prediction and verified in maize [12], in radish [11] and in oilseed rape [10] compared to other vigour testing methods which are complicated and expensive.

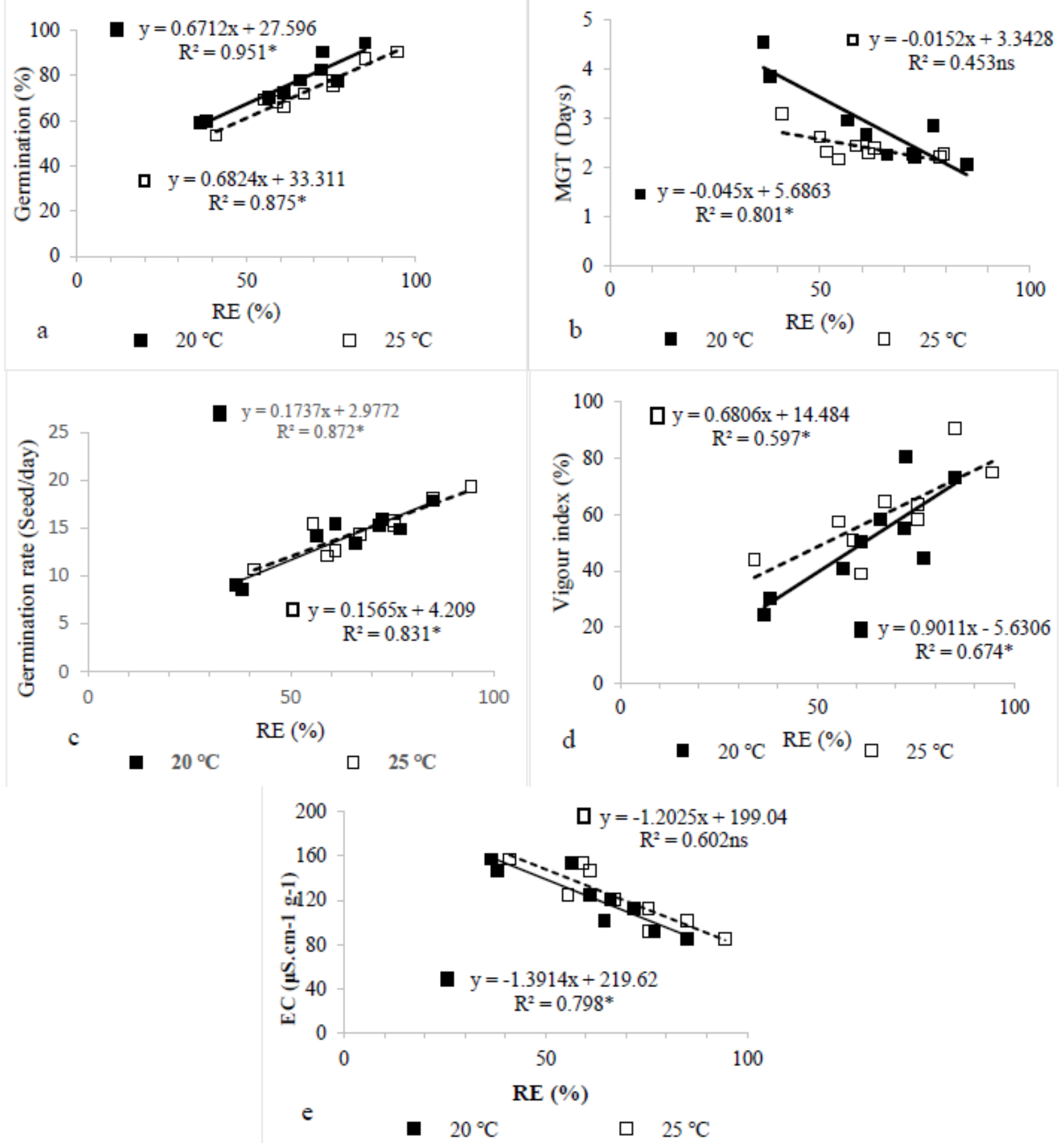

Figure 2. Relationship between a single count of radicle emergence (RE) at 68 hours $\left(25 \pm 1^{\circ} \mathrm{C}\right)$ and 72 hours $\left(20 \pm 1^{\circ} \mathrm{C}\right)$ versus germination percentage (a), MET (b), germination rate (c), vigour index (d) and electrical conductivity (e). $* *=$ significant $\mathrm{P}$ $<0.01$, ns = not significant.

\subsection{Relationship between $\mathrm{RE}$ and seed vigour parameters in the field}

Results on regression analysis indicated that RE can be used as a method for vigour test and a predictor of field emergence (FE) $R^{2}=0.909$ at $20 \pm 1^{\circ} \mathrm{C}$ and $R^{2}=0.732$ at $25 \pm 1^{\circ} \mathrm{C}$ (Fig ure 3A), field emergence rate (FER) $R^{2}=0.829$ $\left(20 \pm 1^{\circ} \mathrm{C}\right.$ ) and $\mathrm{R}^{2}=0.772$ at $25 \pm 1^{\circ} \mathrm{C}$ (Figure 3B), and mean emergence time (MET) $\mathrm{R}^{2}=0.865$ at $20 \pm 1^{\circ} \mathrm{C}$ and $\mathrm{R}^{2}=$ 
0.839 at $25 \pm 1^{\circ} \mathrm{C}$ (Figure 3C). These results showed that field predictions of seed vigour using a single count of RE was more accurate and predictive for seed lots germinated at $20 \pm 1^{\circ} \mathrm{C}$ having higher $\mathrm{R}^{2}$ than when germinated at $25 \pm 1^{\circ} \mathrm{C}$.

Mean emergence time and field emergence rate are parameters which determines seed vigour in the field. Therefore, high correlation coefficients $(r)$ and determination of correlation $\left(\mathrm{R}^{2}\right)$ of $\mathrm{RE}$ was a clear indication that a single and early count of radicle emergence can provide adequate information about seed vigour in the field. Furthermore, a single count of RE can be used as a predictor for field emergence having a 90.9\% prediction rate. These results are in line with [33] in which a single count of RE was predictive to field emergence in oilseed rape. However, $\mathrm{RE}$ at $20 \pm 1^{\circ} \mathrm{C}$ was more accurate and predictive to seed vigour parameters with $\mathrm{R}^{2}$ greater than $\mathrm{R}^{2}$ at $25 \pm 1^{\circ} \mathrm{C}$. The current results have shown that a single count of $\mathrm{RE}$ at selected time $68(25 \pm \mathrm{PC})$ and 72 hours $\left(20 \pm 1^{\circ} \mathrm{C}\right)$ provide a quicker, simpler and more effective assessment of vigour parameters in the field determined by early count of radicle emergence.

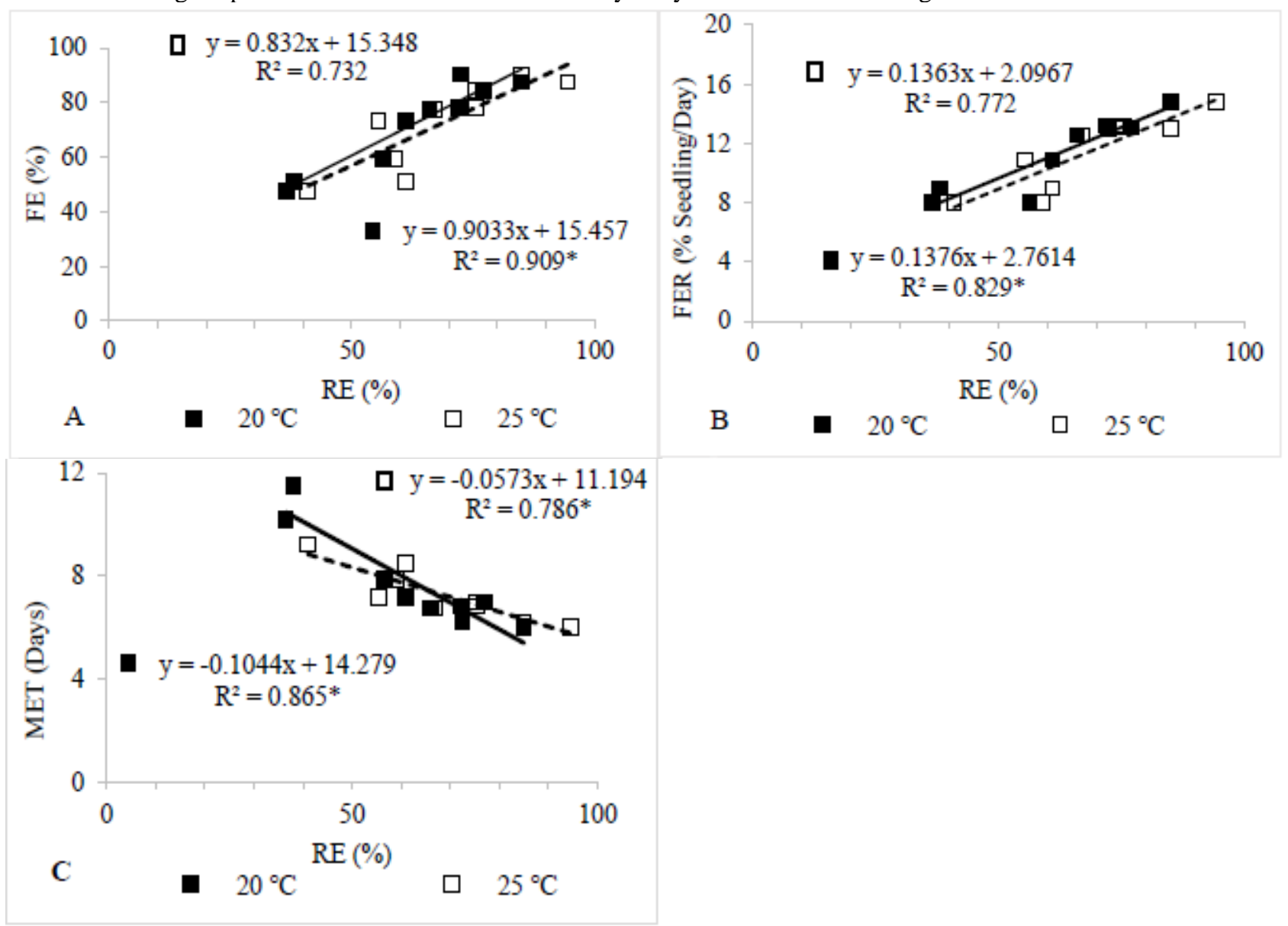

Figure 3. Relationship between RE count at 68 hours $\left(25 \pm 1^{\circ} \mathrm{C}\right)$ and 72 hours $\left(20 \pm 1^{\circ} \mathrm{C}\right)$ versus (A) field emergence (FE), (B) FER and (C) MET.

Based on regression and correlation analysis results, a single count of RE test can be used as a method for seed vigour test and a predictor of a germination percentage in the laboratory and in the field for TSS. The use of artificially aged seed lots with germination \% range of 53\%-94.5\% ensured a realistic approach that involved a range of germinations that were both above and below the minimum required level of seed available on the market for commercial purposes. The findings in the current research concur with [30] that early single count of RE were related to accelerating ageing and controlled deterioration in various crop species such as cotton, watermelon, maize and radish where RE was predictive to the final emergence of normal seedlings in field.

A single count of RE provided a test that is applicable in estimating and predicting normal seedlings within a short period of time e.g., in this research 68 and 72 hours compared to 12 days [12]. The use of RE test as a method for seed vigour analysis has been verified in other horticultural crop seeds. Khajeh-Hosseini et al. [10] found that a single count of RE after 48 hours was related to normal seedling counts of 20 seed lots of oilseed rape with a wide range of normal seedlings ranging from 10 to above $90 \%$ after several years of uncontrolled storage. Research has shown that the use of RE method can be applied to other crops. The current results are in line with [10] that early counts of normal seedlings are regarded as indicator of high-quality seed, in that regard BM1 and TS1 seed lots were considered as seed lots of 
high vigour having higher germination rate and low mean germination time.

The use of RE has demonstrated that early count of RE has the potential to predict seed vigour in the field and has been recognize by ISTA [12] and [31] as a measure of seed performance. Previously, the use of single counts of RE to provide an assessment of MGT was deemed not practical ([32]; [6]; [25]). However, the current findings oppose previous results because single count of RE was predictive to germination percentage, MGT, field emergence and MET which has also been demonstrated in oilseed rape [33] and previously in radish [11]. Furthermore, a single count of RE can identify differences in seed vigour in several species of crops [34].

If the use of radicle emergence in TSS can be adopted and verified, it can be added to a list of crops that have already been validated where a single count of radicle emergence is used as a method for vigour test, predicting field emergence for maize, oilseed rape [34] and radish [35]. Studies have indicated that a single count of radicle emergence was related to seed vigour in other species where the optimum single RE count during germination in oil seed and in cotton were predictive to germination percentage and field emergence [25].

\section{Conclusion}

Radicle emergence has been found to be quick, simple and an effective method in predicting field emergence in TSS at $68 \mathrm{~h}$ or $72 \mathrm{~h}$ when seed lots are germinated at $25 \pm 1^{\circ} \mathrm{C}$ and at $20 \pm 1^{\circ} \mathrm{C}$ respectively. Since a single count of radicle emergence correlated well with other vigour tests in the laboratory and in the field, then it can be used as one of the methods for seed vigour testing for TSS.

\section{Acknowledgements}

This research was supported by the Ministry of Research and Higher Education, Indonesian government. The authors would like to thank all the students in The Study Program of Seed Science and Technology, Bogor Agricultural University for their support.

\section{References}

[1] [BPS] Badan Pusat Statistika. (2017). Statistik Luas Panen dan Produktivitas Bawang Merah Nasional. Jakarta, West Java, Indonesia. Retrieved from http://www.bps.go.id.

[2] Idhan, A., Syam'un E., Zakaria, B., Riyadi, M. (2015). Potential Selection of Flowering and Tuber Production in Fourteen Onion Varieties. Internl J. of Current Rese in Biosci and Plant Biol., 7(2): 63-67.

[3] Demir, I., C. Cebeci, and T. Guloksuz. (2012). Electrical conductivity measurements to predict germination of commercially available radish seed lots. Seed Sci. \& Technol., 40: 229-237. doi: https://doi. org/10.15258/sst.2012.40.2.08.

[4] Powell, A. A. and S. Matthews. (2012). Seed ageing /repair hypothesis leads to new testing methods. Seed Sci.\& Technol., 34: $15-25$.

[5] Marin, M., G. Laverack, A. A. Powell, and S. Matthews. (2018). Potential of the electrical conductivity of seed soak water and early counts of radicle emergence to assess seed quality in some native species. Seed Sci \& Technol., 46(1): 71-86.

[6] Matthews, S., M. H. Wagner, L. Kerr, G. McLaren, and A. A. Powell. (2012). Automated determination of germination time courses by image capture and early counts of radicle emergence lead to a new vigour test for winter oilseed rape (Brassica napus). Seed Sci. \& Technol., 40: 412-424.

[7] Matthews, S. and M. Khajeh-Hosseini. (2006). Mean germination time as an indicator of emergence performance in the soil of seed lots of maize (Zea mays). Seed Sci. \& Technol., 42: 339-347. doi: doi.org/10.15258/sst.2006.34.2.09.

[8] Demir, I., S. Ermis, K. Mavi, and S. Matthews. (2008). Mean germination time of pepper seed lots (Capsicum annuum L.) predicts size and uniformity of seedlings in germination tests and transplant modules. Seed Sci. \& Technol.,36: 21-30.

[9] Mavi, K., F. Mavi, I. Demir, and S. Matthews. (2014). The electrical conductivity of seed soak water predicts seedling emergence and seed storage potential in commercial seed lots of radish. Seed Sci. and Technol., 42: 76-86.

[10] Khajeh-Hosseini, M., M. Nasehzadeh, and S. Matthews. (2010). Rate of physiological germination relates to the percentage of normal seedlings in standard germination tests of naturally aged seed lots of oilseed rape. Seed Sci. and Technol., 38: 602-611.

[11] Mavi, K., A. A. Powell, and S. Matthews. (2016). Rate of radicle emergence and leakage of electrolytes provide quick predictions of the percentage normal seedlings in standard germination tests of radish (Raphanus sativus). J. Seed Sci and Technol., 44: 393-409.

[12] International Seed Testing Association (ISTA). (2014). International Rules for Seed Testing. Zurich, Switzerland: ISTA.

[13] Khajeh-Hosseini, M., A. Lombholt, and S. Matthews. (2009). Mean germination time in laboratory estimates the relative vigour and field performance of commercial seed lots of maize (Zea mays L.). Seed Sci and Technol., 37: 446-456.

[14] Wagner, M. H., D. Demilly, S. Ducournau, C. Durr, and J. Léchappé. (2011). Computer vision for monitoring seed germination from a dry state to young seedlings. Seed Testing Intl., 142: 49-51. 
[15] Rao, R. G. S., P. M. Singh, and M. Rai. (2006). Storability of onion true seeds and effects of packaging and storage conditions on viability and vigour. Scientia Horticulturae, 110: 1- 6.

[16] Feda, N., Paramesh, B. Rafi, and A. Ahmad. (2018). Influence of accelerated ageing test on seed quality of onion (Allium cepa L.). Intl. J. of Multidisciplinary Educ and Res., 3(3): 1-4.

[17] Rodo, A. B. and J. Marcos-Filho. (2003). Onion seed vigour in relation to plant growth and yield. Hort Brasileira, Brasília., 21(2): 220-226.

[18] Ellis, R. H. and E. H. Roberts. (1981). The quantification of ageing and survival in orthodox seeds. Intl. J. of Seed Sci. \& Technol., 9: 373-409.

[19] Maguire, J. (1962). Speed of germination-Aid in selection and evaluation for seedling emergence and vigour. Crop Sci., 2: 176-177.

[20] Sadeghianfar, P., M. Nazari, and G. Backes. (2019). Exposure to Ultraviolet (UV-C) Radiation Increases Germination Rate of Maize (Zea maize L.) and Sugar Beet (Beta vulgaris) Seeds. J. Plants., 1: 1-6. doi: doi:10.3390/plants8020049.

[21] Dos Santos Dias, D. C. F., M. C. Bhering, D. Tokuhisa, and P. C. Paulo. (2006). Electrical conductivity test to evaluate onion seed vigour. Brazilian J. of Seeds., 28(1): 154-163.

[22] RStudio Team. (2015). RStudio: Integrated Development for R. RStudio, Inc., Boston, MA URLhttp://www.rstudio.com/.

[23] Kapoor, R., A. Arya, M. A. Siddiqui, A. Amir, and H. Kumar. (2010). Seed deterioration in chickpea (Cicer arietinum L.) under accelerated ageing. Asian J. of Plant Sci.,9: 158-162. doi:doi:10.3923/ajps.2010.158.162.

[24] JYoti, J. and C. P. Malik. (2013). Seed deterioration: Seed viability, seed deterioration and seed quality improvements in stored. Intl. J. of Life Sci, Biotechnol. and Pharmaceutical Res., 2: 374-385.

[25] Mathews, S. and A. A. Powell. (2011). Towards automated single counts of radicle emergence to predict seed and seedling vigour. Seed Testing Intl., 141: 39-45.

[26] Demir, I., K. Mavi, B. B. Kenanoglu, and S. Matthews. (2008). Prediction of germination and vigour in naturally aged commercially available seed lots of cabbage (Brassica oleracea var. capitata) using the bulk conductivity method. Seed Sci. \& Technol., 36: 509-523.

[27] Mavi, K., I. Mavi, S. Demir, and S. Matthews. (2010). Mean germination time estimates the relative emergence of seed lots of three cucurbit crops under stress conditions. Seed Sci. Technol., 38: 14-25.

[28] Lv, Y. Y., Y. R. Wang, and A. A. Powell. (2016). Frequent individual counts of radicle emergence and mean germination time predict seed vigour of Avena sativa and Elymus nutans. Seed Sci. \&Technol., 44: 189-198.

[29] Mirdad, Z., A. A. Powell, and S. Matthews. (2006). Prediction of germination in artificially aged seeds of Brassica spp. using the bulk conductivity test. Seed Sci and Technol., 34, 273-286.

[30] Ermis, S., M. Karslioglue, E. Ozden, and E. Demir. (2015). Use of single radicle emergence count as a vigour test prediction of seedlings emergence potential of leek seed lots. Seed sci. \& technol., 43:308-312.

[31] Bello, P. and K. J. Bradford. (2016). Single-seed oxygen consumption measurements and population-based threshold models link respiration and germination rate under diverse conditions. Seed Sci. Res., 26: 199-221.

[32] Matthews, S., E. Noli, I. Demir, M. Khajeh-Hosseini, M. H. Wagner. (2010). Evaluation of seed quality: from physiology to international standardisation. Seed Sci Res., 20: 69-73.

[33] Matthews, S., M. H. Wagner, L. Kerr, G. McLaren, and A. A. Powell. (2018). Potential for early counts of radicle emergence and leakage of electrolytes as quick tests to predict the percentage of normal seedlings. Seed Sci. \& Technol., 46(1): 1-18.

[34] International Seed Testing Association (ISTA). (2017). International Rules for Seed Testing. Zurich, Switzerland: ISTA.

[35] Powell, A. A. and K. Mavi. (2016). Application of the radicle emergence test to radish (Raphanus sativus). Basserdorf: International Seed Testing Association. J. Seed Sci. \& Technol., 44: 410-418. 